\title{
Consciousness or safety? Gender issues in an internal selection process
}

\author{
LUIZA WANKe Freitas ${ }^{1}$ \\ VIVIAN LUIZ COCO $^{1}$ \\ LUCIA BARBOSA DE OLIVEIRA ${ }^{2}$ \\ ana Christina Celano Teixeira ${ }^{1}$ \\ ${ }^{1}$ FACULDADES IBMEC, RIO DE JANEIRO - RJ, BRAZIL \\ 2 Fundação Getulio Vargas (FGV EBAPE) / Escola Brasileira de AdMinistração Pública e de EMPreSAS, Rio de Janeiro - RJ, BRAZIL
}

\begin{abstract}
The case addresses the situation experienced by Gustavo, manager of a team of six analysts in the financial department of a large public bank. One of the team's senior analysts had been promoted to manager in another area, and he was faced with the need to choose one of his team's full analysts for the position. After analyzing the candidates' skills and profile, Gustavo was convinced that Clarice was the most prepared to take the job. At the same time, he knew that Clarice could become pregnant in the near future and, if that happened, due to a special medical condition, she would be absent for a year, including sick and maternity leave. Gustavo is therefore faced with a dilemma. Should he take into account only the candidate's skills, or would it also be necessary to consider the repercussion among the other colleagues and the impact on the work of the entire team if she became pregnant soon after the promotion?
\end{abstract}

Palavras-chave: Recruitment and selection. Gender. Leadership. Diversity. Glass ceiling.

\section{Consciência ou segurança? Questões de gênero num processo seletivo interno}

\section{Resumo}

O caso aborda a situação vivenciada por Gustavo, gestor de uma equipe de seis analistas da diretoria financeira de um grande banco público. Um dos analistas seniores da equipe havia sido promovido a gerente de outra área e ele se viu diante da necessidade de escolher um dos analistas plenos de sua equipe para o cargo. Analisadas as competências e o perfil dos candidatos, Gustavo tinha a conviç̧ão que Clarice era a mais preparada para assumir a vaga. Ao mesmo tempo, ele sabia que Clarice poderia engravidar em um futuro próximo e, se isso ocorresse, por uma condição médica especial, ela passaria um ano ausente, somadas as licenças saúde e maternidade. Gustavo se vê, portanto, diante de um dilema. Deveria ele levar em conta apenas as habilidades da candidata, ou seria também necessário considerar a repercussão entre os demais colegas e o impacto sobre o trabalho de toda a equipe caso ela engravidasse logo após a promoção?

Keywords: Recrutamento e seleção. Gênero. Liderança. Diversidade. Teto de vidro.

\section{¿Conciencia o seguridad? Cuestiones de género en un proceso de selección interno}

\section{Resumen}

El caso aborda la situación vivida por Gustavo, gerente de un equipo de seis analistas de la dirección financiera de un gran banco público. Uno de los analistas senior del equipo fue ascendido a gerente de otra área y Gustavo necesitó elegir a uno de los analistas plenos de su equipo para suplir la vacante. Tras analizar las habilidades y el perfil de los candidatos, se convenció de que Clarice era la más preparada para asumir el puesto. Al mismo tiempo, sabía que ella podría quedar embarazada en un futuro cercano y, si eso sucediese, debido a una condición médica especial, estaría ausente durante un año -sumadas las licencias de salud y maternidad-. Por lo tanto, Gustavo se encontró ante un dilema. ¿Debería tener en cuenta solo las habilidades de la candidata, o también sería necesario considerar la repercusión entre los demás compañeros y el impacto en el trabajo de todo el equipo si ella quedara embarazada poco después del ascenso laboral?

Palabras clave: Reclutamiento y selección. Género. Liderazgo. Diversidad. Techo de cristal. 


\section{INTRODUCTION}

On a day that seemed like any other, Gustavo, an experienced banking executive, aged 50 with a 30 -year career, was preparing to have lunch with Abigail, a dear co-worker. He was concerned with how to resolve an issue regarding a position he had just opened in his area that would result in the promotion of one of his team members. Among the three options of analysts eligible for the new position, one name seemed the most suitable to him: Clarice. However, this might not be such an easy decision.

Gustavo and Abigail had been friends for almost 10 years and talked about everything. As soon as they sat down at their usual restaurant table, he started the conversation by telling he that his daughter was pregnant and how happy he was with the arrival of his first granddaughter. This prompted Abigail to say that she had been with Clarice on the previous weekend, one of the analysts who was part of Gustavo's team.

He immediately asked how she was doing, as Clarice had recently lost a baby at six months pregnant. A very sad story, which moved him a lot and the whole team. Abigail said that Clarice was a little better, as her doctor had concluded the diagnosis about what led to the loss of the baby, indicating that a next pregnancy would be possible, provided that the necessary care was taken to avoid a new occurrence.

Gustavo was very happy to know that Clarice was calmer and felt compelled to ask about the diagnosis. Abigail explained that it was a condition on the cervix and that it was possible for Clarice to have another baby, provided that she had a surgical procedure in early pregnancy and remained at bed rest until birth. Trying to not let it show, Gustavo felt a chill in his stomach as he thought about his plans to appoint Clarice to the position of senior analyst that had just become vacant. He was bothered by the fact that being in the year 2019 did not make this decision easier for a manager.

\section{Gustavo}

Gustavo was from Rio de Janeiro and, in 1989, at the age of 20, he passed the public competition to become a clerk of a large public bank. The contest was national and he was called to take office at a small agency, in the countryside of Rio Grande do Sul. There he went, with his girlfriend, who quickly became his fiancée and later, wife. There Gustavo began to build his life and his career. After five years in the company, a relatively short time, he became an account manager and managed to return to Rio de Janeiro. It was at that time, in 1994, that his daughter was born.

A very dedicated employee, he moved up positions little by little, within the perspectives that the company offered and that were closely related to his time working there. Gustavo worked in several agencies and also in different operational areas until, with a 15-year career, he passed a selection to work as a junior analyst for the bank's financial department.

As a part of the board, he dedicated himself especially to financial products, which made him experienced in the subject and admired for such experience. Two years later, he was promoted to full analyst and, in the following three years, to senior analyst. Gustavo was often recognized by his superiors for the technical quality of his work and for his dedication. Among his colleagues, he was recognized as the person who brought everyone together for the sake of the company and who helped to maintain a great environment.

As he constantly received positive feedback, Gustavo felt prepared to take on the position of manager. After being passed over on a few occasions and after eight years as a senior analyst, the opportunity arose a major restructuring in the board. Gustavo was finally appointed as manager.

His team was composed of six analysts - three full analysts and three senior analysts. Gustavo was an extremely supportive manager and cared for his team with attention and affection. Always attentive to the personal needs of each one, he knew their stories and he was willing to help everyone. As he was profoundly knowledgeable of the technical aspects of the work, he closely managed the performance of tasks, ensuring the optimal performance of the team's activities.

At times this very human and nurturing aspect of Gustavo caused him some difficulty in giving negative feedbacks or demanding better results from the employees who were underperforming. He would assign the most complex activities to the most skilled employees, which ended up leaving less activities for those showing lower performances. 
In 2019, when he completed 50 years of age and 30 years of career, two of them as manager of this team, Gustavo began to plan his retirement. In a short time, he would be dedicating himself exclusively to his family and granddaughter who was on the way.

\section{The organization and the internal environment}

The bank where Gustavo worked was a large public bank, with more than 70 thousand employees and agencies spread across Brazil. At the time Gustavo started his career, the organization had over 100 years of history and was very conservative, with a very strong culture. The organizational environment was welcoming and the employees considered the colleagues almost as members of the own family, such was the bond between them. At that time, rank climbing was linked to career time and there were hardly any women in management positions.

As time went by, the culture changed and, little by little, promotions became more motivated by assessment of the employees' skills and competencies. A support system for internal selection processes was implemented at the bank, in which the employees registered their educational background, including specialization courses, in addition to positions held and the results of the latest performance evaluations. The system was usually employed at the beginning of the processes and ranked the employees according to the score obtained considering the aspects parameterized by each manager. Thereafter, the selection processes normally followed other steps, such as interviews or group dynamics.

The financial department was located in Rio de Janeiro and had about 300 employees; it was made up of 50 managers and 250 analysts - 100 junior analysts, 90 full analysts and 60 senior analysts. In the group of managers, there were only two women. In the technical roles, gender balance was greater: $45 \%$ of the positions were held by women.

Usually, the board used the support system in the selection processes for junior analyst, choosing the highest scoring employees from other areas. In the case of selection processes for the remaining functions, most managers chose to promote employees from their own teams.

\section{The selection for senior analyst}

A senior analyst from the team managed by Gustavo had just been promoted to manager of another team through an internal selection process. The board gave Gustavo the autonomy to choose who would be appointed to the newly opened position. Despite the existence of the system for internal selection, Gustavo chose not to resort to it, as he considered that his direct evaluation as manager on a daily basis was more important than the score calculated by the system.

Ana Beatriz was the oldest full analyst, she was 45 years old, 25 years in the company and had been in the position for 8 years. The executive of the area, Gustavo's boss, supported her appointment, because he considered that the time in the company was an important factor in the decisions regarding promotions. However, Gustavo considered the employee's performance to be less than desirable for a senior analyst, as she lacked proactivity and initiative. Gustavo had to constantly remind her several times for each activity that was assigned to Ana Beatriz and, sometimes, he needed to intervene to solve more complex problems.

Paulo was another full analyst in Gustavo's team. He was 32 years old, 8 at the company and a little over a year ago he had been promoted to full analyst. During this short period, Gustavo noticed a lot of potential in Paulo, an intelligent professional who demonstrated good understanding of the technical aspects of the work. Yet, Gustavo felt insecure about Paulo's behavioral skills. Would he have the balance and dedication expected from someone committed to the team and the organization? In some interactions since joining the team, Gustavo realized that Paulo lacked interest and initiative in solving the demands of the area.

Clarice was the third full analyst on the team. She was 28 years old, 8 years with the company and 2 as a full analyst. Her recent history was marked by a dramatic fact. A few months ago, she had lost her baby when she was six months pregnant. The baby was born alive, but died an hour after the birth, which led her to take compulsory maternity leave. Clarice even resorted to all the company's human resources bodies to give up her maternity leave without success. At that moment, it was two weeks before she returned to work. 
Although Clarice had only been on the team for two years, Gustavo considered her ready for the senior analyst position. He would trust her with the most complex problems, and she solved them quickly and with quality. In addition, she was always interested in learning and collaborating with the team.

The lunch with her friend, Abigail, happened exactly during the process of analyzing and defining the team's internal promotion. In that informal conversation, Abigail revealed to Gustavo that, in a conversation, Clarice confided to her that her obstetrician had completed the diagnosis about what led to the loss of the baby. Clarice's problem would lead to the need for a surgical intervention and bed rest in the case of a future pregnancy, which would further prolong her absence due to health and maternity leave in the future.

Gustavo came back from lunch bewildered. He was sure that Clarice was the right name for the position, but this new information raised many doubts. If he named Clarice and then she became pregnant, he would have to manage the team for one year with one less senior analyst. And, on top of that, he would have to deal with Ana Beatriz's frustration.

If he chose to appoint Ana Beatriz as a senior analyst, he knew that her performance could jeopardize the team's activities. Although she was more experienced, Gustavo did not trust the analyst's work. And he thought it would be unfair to promote her when she was not, in his opinion, the most competent. Similarly, he believed that it would also be unfair to promote Paulo, since he would be rewarding a person with questionable attitudes. Both the appointment of the newcomer and Ana Beatriz would avoid many problems in case Clarice was chosen and chose to get pregnant again. What to do? 


\section{TEACHING NOTES}

\section{Teaching objectives}

Based on the reading and analysis of the proposed teaching case, it is possible to approach and reflect on topics related to human resources management and organizational behavior, with emphasis on:

- recruitment and selection of people;

- team leadership;

- gender diversity and inclusion/discrimination in organizations.

It is also expected that the discussion of this case will allow students to:

- exercise critical thinking in situations that involve choices between excluding alternatives;

- reflect on a problem from different angles and points of view;

- discuss and analyze an ethical dilemma, taking a clear stance.

\section{Sources and methods of collection}

The data that allowed the development of this case was obtained through the personal experience of one of the authors and also from public documents of the organization in question. The names of everyone involved have been changed to preserve their anonymity.

\section{Suggested disciplines for use of the case}

The teaching case is intended for graduate and postgraduate courses in the field of Administration, particularly in disciplines such as Human Resource Management, Organizational Behavior and Leadership, or another whose subject involves issues related to gender diversity and discrimination in organizations.

Possible tasks to propose to the students

The situation experienced by Gustavo allows for discussion of several issues regarding people management. Firstly, students can be encouraged to expose their experiences regarding the selection processes of which they have been part of - both internal and external. Examples may arise among women of selection or promotion processes in which they have felt disadvantaged in relation to men.

In addition to this first exchange of experiences, the following questions can be proposed as a way of stimulating the debate:

1. How would you rate Gustavo's leadership style? And the profile of his subordinates?

2. Which factors should be taken into consideration in an internal selection process?

3. Do you believe that women are or can be discriminated in selection processes? Explain.

4. How would you explain the fact that women are a minority in the upper echelons of organizations?

5. Which benefits can an organization gain by promoting gender equity at higher hierarchical levels?

6. Who would you promote to senior analyst if you were in Gustavo's position? Justify your answer.

The first question allows for a discussion on the topic of leadership, focusing on Gustavo's leadership style. This debate can be conceptually based on the situational theory of Hersey and Blanchard (Blanchard, 2012) or on the model proposed by Goleman (2000), both discussed in greater depth in the theoretical framework. Complementarily, one can discuss the profile of Gustavo's team members presented in the case - Clarice, Ana Beatriz and Paulo -, also based on the situational theory of Hersey and Blanchard (Blanchard, 2012). 
In the second question, the internal selection process for the position of senior analyst is discussed. Here, the teacher can conceptually address each of the stages of a selection process, with emphasis on the knowledge, skills and attitudes needed for the job and the methods of evaluating candidates for the position. Then, the teacher can stimulate the debate around other topics related to internal selection processes, including: the role of seniority in decisions about promotions, stimulating diversity (gender and others) and, still, the current capacity versus future potential issue.

The third question allows for a deeper look into the problem of the glass ceiling in organizations, defined as real barriers, but frequently imperceptible, faced by women in their access to higher positions in the hierarchy of the organizations (Eagly \& Carli, 2007; Steil, 1997). In the situation reported in the case, the analyst Clarice may lose her chance of being promoted due to a possible pregnancy.

Continuing the debate, and with reference to the fourth question, the teacher can display data with the percentage of men and women in leadership positions in organizations and then ask students to reflect on the causes of this phenomenon. In question five, the teacher can close the debate started in the third question by stimulating reflection among the students about the advantages of diversity, not only in relation to gender, but including other dimensions such as race and ethnicity, sexual orientation, and physical and mental skills.

In the sixth and final question, the students should take a stance and choose the most appropriate professional to take the position of senior analyst, considering the information presented in the case.

\section{Suggested script for applying the case}

The application of the case can be carried out before or after showing of the theories and concepts to be worked on. If the conceptual stage occurs before the discussion of the case, it is important that students read the indicated material in advance, allowing them to have the necessary theoretical background for the discussion of the proposed topics.

The reading of the case, estimated at approximately 20 minutes, can be done in the classroom or at home, prior to class. After reading it, it is proposed that an initial analysis of the case be made, with the identification of the proposed dilemma. This activity can be stimulated by the teacher through questions such as: what is the dilemma in which Gustavo finds himself? Who are the main characters and their roles in this dilemma?

After this first analysis, which can be done in plenary, with all participants, it is suggested to divide the class into groups of three to five students, so that the questions proposed here or others that the teacher considers relevant to the topic of class be discussed. By virtue of the number of questions, the teacher can allow between 20 and 40 minutes for the groups to discuss them. Then, the class would meet again in plenary to debate the questions and consolidate the answers with everyone's contribution.

Depending on the level of knowledge of the class about the theoretical framework, the teacher can make a brief presentation of the central concepts of the case related to internal selection and promotion of employees, leadership profiles and/or gender diversity issue in organizations.

In the last question, related to Gustavo's decision, the teacher has the option of applying the debate technique, dividing the class into three groups, so that each one defends, respectively, the promotion of Ana Beatriz, Clarice and Paulo. Each group would be given 20 minutes to consolidate their arguments. Each group would choose a debater and the teacher would lead the debate, with 5 minutes for each one to present their arguments. Then another 5 minutes for reply and rejoinder on both sides.

It is also recommended that the teacher queries the students before and after the discussion (using applications such as google forms, kahoot, mentimeter or similar), aiming to evaluate the percentage of students who chose each of the three candidates for promotion and, also, if there were changes of opinion in view of the arguments presented by the groups. To end the class, the teacher can present the results of the two surveys, make a connection with the theories worked on, and then report the outcome of the real case to the students. 


\section{Case closure}

In the real case, Gustavo called Clarice to talk and shared his dilemma with her. He explained that he had been intending to name her when he heard from Abigail about her health problem. Although he was convinced that Clarice had the necessary skills for the position, he was unsure about appointing her, because if she became pregnant soon after taking office, Gustavo would have to deal with the accumulation of work and with Ana Beatriz's possible outrage.

After this explanation, Gustavo presented Clarice with the following proposal: he would be willing to name her, as long as she went at least a year without becoming pregnant. Clarice accepted the proposal and was appointed senior analyst of the team.

\section{THEORETICAL REFERENTIAL}

In order to contribute to the theoretical basis of the discussion questions, a brief review of the literature was prepared on the topics of leadership, recruitment and selection, and gender diversity in organizations, with emphasis on the glass ceiling phenomenon.

\section{Leadership}

In the areas of management and organizational behavior, the topic of leadership has been widely discussed. There are many definitions found for the concept of leadership, as well as theories to explain it in all its complexity. According to Yukl (2013), most definitions involve the idea of a process in which one person exerts influence over others in order to direct the activities of a group or organization. The author also presents his own definition.

"Leadership is the process of influencing others to understand and agree about what needs to be done and how to do it, and the process of facilitating individual and collective efforts to accomplish shared objectives" (Yukl, 2013, p. 23)

Regarding leadership theories, it is possible to organize them into three groups (Robbins, Judge \& Sobral, 2011). The first involves those that focused on the personal characteristics or personality traits of the leaders. In the second, there are behavioral theories, which sought to investigate to what extent the leader's effectiveness would depend more on his behavior than on personal characteristics. Finally, more recently, contingential theories of leadership have emerged, whose essential proposition is that the leader's effectiveness would be related to his or her ability to tailor his or her leadership style to the situation in which he or she finds himself or herself (Robbins et al., 2011; Yukl, 2013).

Within the scope of contingency theories, several researchers have proposed their own models, taking into account different aspects of the situation, including the organizational environment, the nature of the work, the profile and the motivation of the subordinates, the quality of the relationship between the leader and his subordinates, the degree of cooperation between team members, in addition to the profile of the leader himself (Robbins et al., 2011; Yukl, 2013).

From this set, one can highlight the theory of situational leadership by Hersey and Blanchard, according to which the leader would need to adapt the leadership style to the profile of the subordinates, with emphasis on their skills and motivations (Blanchard, 2012; Yukl, 2013). According to the theory, the subordinates can be classified in four stages of development, these being: the excited beginner (D1 - low competence, high commitment); the disappointed apprentice (D2 - low/some competence, low commitment); the capable but cautious employee (D3 - moderate to high competence, variable commitment); and the self-confident achiever (D4 - high competence, high commitment). Depending on the stage of development of the subordinate, it is recommended that the leader adopt the corresponding style: E1 - direction; E2 - coaching; E3 - support; E4 - delegation (Blanchard, 2012). Each of these styles involves a combination between supportive behavior and directive behavior, as illustrated in Figure 1. 
Figure 1

Situational leadership model

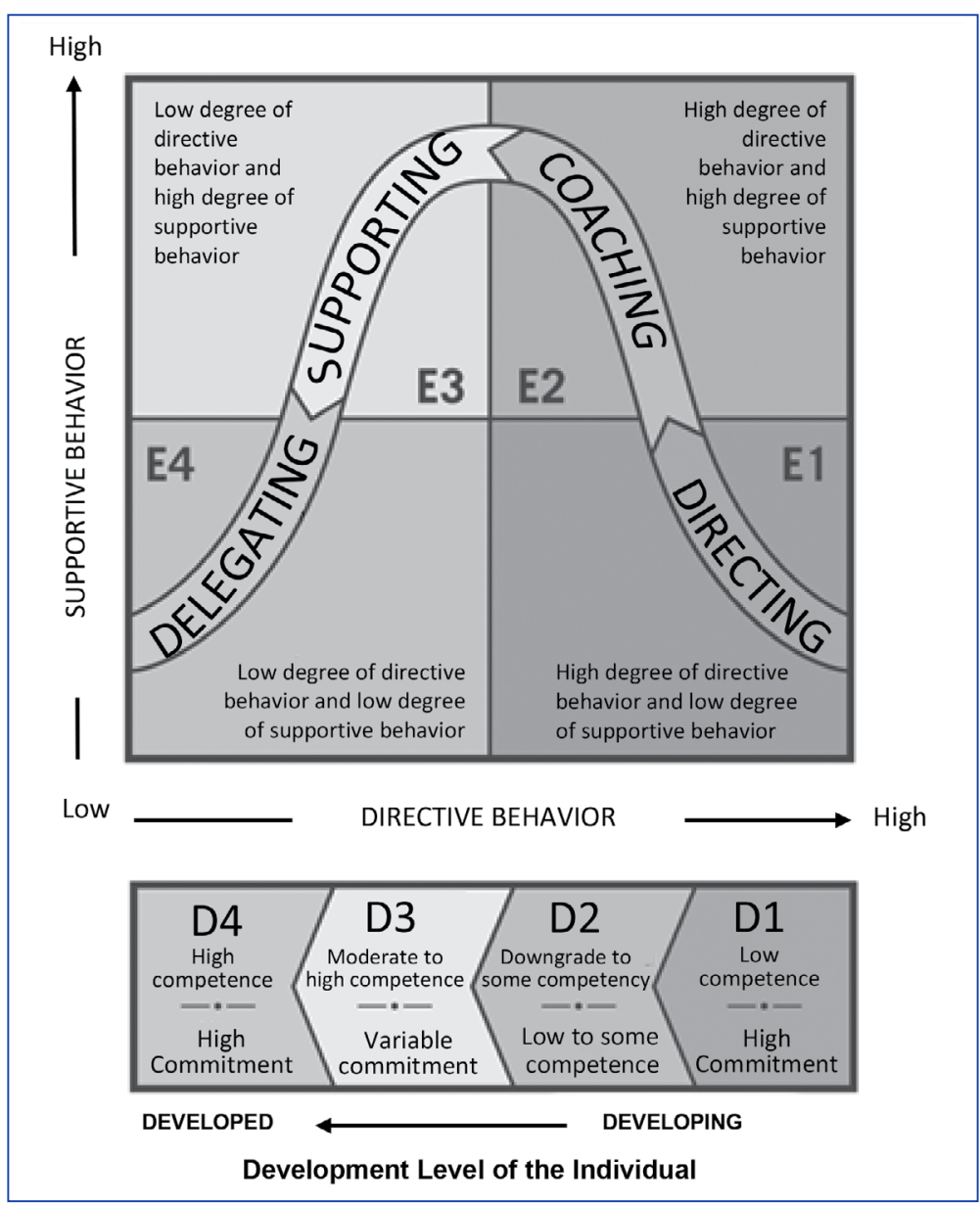

Source: Blanchard (2012, p. 75).

Thus, in order to be effective, the leader would need to be able to identify the level of development of each one of his subordinates and also have the flexibility to adapt his management style to the respective levels.

Through empirical research with a wide set of leaders worldwide, Goleman (2000) proposed another contingency model, composed of six leadership styles, as shown in Box 1. As can be observed, each style is presented as more appropriate to certain situations and having different repercussions on the subordinates, whilst also having a more or less positive or negative effect on the organizational climate. The author also proposes that the most effective leaders are those capable of adopting different styles, depending on the situation they find themselves in. 
Box 1

Leadership styles

\begin{tabular}{|c|c|c|c|c|}
\hline Leadership style & How it's seen & $\begin{array}{l}\text { Impact on the } \\
\text { environment }\end{array}$ & $\begin{array}{c}\text { The Style in a } \\
\text { phrase }\end{array}$ & When the style works best \\
\hline $\begin{array}{c}\text { Visionary } \\
\text { (authoritative) }\end{array}$ & $\begin{array}{l}\text { It drives people towards } \\
\text { shared goals. }\end{array}$ & $\begin{array}{l}\text { Most strongly } \\
\text { positive }\end{array}$ & "Come with me". & $\begin{array}{l}\text { Circumstances that require } \\
\text { vision and clear direction. }\end{array}$ \\
\hline Coaching & $\begin{array}{l}\text { Connects individual needs } \\
\text { to the team goals. }\end{array}$ & Positive & "Try this". & $\begin{array}{l}\text { To promote the development } \\
\text { of team members. }\end{array}$ \\
\hline $\begin{array}{l}\text { Gregarious or } \\
\text { Affiliative }\end{array}$ & $\begin{array}{l}\text { Creates harmony and builds } \\
\text { emotional bonds. }\end{array}$ & Positive & $\begin{array}{l}\text { "People come } \\
\text { first". }\end{array}$ & $\begin{array}{c}\text { When there are problems } \\
\text { in the team or in } \\
\text { stressful situations. }\end{array}$ \\
\hline Democratic & $\begin{array}{l}\text { He values ideas and } \\
\text { gets commitment } \\
\text { through participation. }\end{array}$ & Positive & $\begin{array}{l}\text { "What do you } \\
\text { think?" }\end{array}$ & $\begin{array}{c}\text { To build consensus and } \\
\text { get input from valuable } \\
\text { employees. }\end{array}$ \\
\hline Pacesetting & $\begin{array}{l}\text { Set challenging and } \\
\text { exciting goals. }\end{array}$ & Negative & $\begin{array}{l}\text { "Do as I do, } \\
\text { now". }\end{array}$ & $\begin{array}{c}\text { To obtain quick results } \\
\text { from a competent and } \\
\text { motivated team. }\end{array}$ \\
\hline Commanding & $\begin{array}{l}\text { Relieves fear by giving clear } \\
\text { instructions in an emergency. }\end{array}$ & Negative & "Do as I say." & In crisis situations. \\
\hline
\end{tabular}

Source: Based on Goleman (2000).

\section{Recruitment and selection of people}

Human resources management is composed of a series of operations - including recruitment and selection, training and development, performance evaluation, compensation and reward - aiming to provide the organization with a qualified and motivated workforce to contribute to the achievement of its strategic objectives (Brito \& Oliveira, 2014; Dessler, 2013).

Recruitment and selection are two processes that are often dealt with together, but fulfill different functions. While recruitment involves attracting a set of candidates to positions to be filled in an organization (Breaugh, 2008), selection corresponds to the choice of the most suitable candidate for each position (Bohlander \& Snell, 2015). In this selection process, a candidate with the best knowledge, skills and attitudes necessary for his individual performance in the position is usually sought, but factors such as retention, team performance and the strategic objectives of the organization can also be considered (Ryan \& Ployhart, 2014).

There are two approaches for recruitment, which can be done both internally - with people who are already part of the organization's staff - and externally (Bohlander \& Snell, 2015; Dessler, 2013). When an organization prioritizes internal recruitment, only people for base positions are hired externally, while the remaining positions are filled through the promotion or transfer of employees from other areas. When external recruitment is prioritized, candidates from the outside of the organization are sought to fill the open positions, whatever they may be. Of the various advantages associated with internal recruitment, the motivation of employees for good performance stands out, considering that they can be rewarded with a promotion or moving horizontally. In addition, employees may also feel encouraged to invest in their own training, given the prospect of promotion or change in role (Bohlander \& Snell, 2015).

The selection process can be divided into three steps. Firstly, it is necessary to map the set of knowledge, skills and attitudes that will be evaluated in each candidate. These factors depend on the function to be performed and encompass both cognitive and non-cognitive skills, including personality, emotional intelligence, interests and integrity (Bohlander \& Snell, 2015; Ryan \& Ployhart, 2014). Then, each candidate is evaluated in relation to the aspects identified in the previous step, through different evaluation methods. Among such methods, the most common are cognitive skills tests, personality tests, integrity tests and evaluation centers, in addition to group dynamics and personal interviews (Bohlander \& Snell, 2015; Dessler, 2013). 
Finally, it is necessary to make the final decision on the most suitable candidate. Two approaches can be adopted, clinical and statistical (Bohlander \& Snell, 2015). The clinical approach - carried out by decision makers - involves a qualitative and holistic analysis of each candidate. One risk that is taken with this approach is the influence of stereotypes and other common biases in decision making. The statistical approach, being more objective, contributes to reduce such biases. In this case, candidates receive a score for each evaluation criterion and the chosen one is the one with the highest total score. In terms of criteria, higher value points can be set for those considered more important and, still, cut-off values can be created, so that candidates who do not obtain a minimum score in any criterion are disregarded (Bohlander \& Snell, 2015).

Throughout the selection process, Bohlander and Snell (2015) draw attention to some important aspects to consider:

- Should one focus on the candidate's suitability for the current position or his or her potential for progress in the organization?

- Should candidates with higher qualifications than necessary be considered?

- Should candidates who are not fully qualified, but with potential, be considered?

- How to deal with diversity issues?

Regarding this last issue, it should be pointed out that the theme of diversity has received increasing attention in organizations, including dimensions such as gender, age, race and ethnicity, sexual orientation and physical and mental skills (Nkomo, Bell, Roberts, Joshi \& Thatcher, 2019; Shore et al., 2009). In the next section, gender diversity in organizations will be discussed in greater depth, with emphasis on the relatively low participation of women in leadership positions.

\section{Gender diversity and glass ceiling}

Much has been discussed on the importance of diversity in organizations, including gender diversity (Nkomo et al., 2019; Shore et al., 2009). A study conducted by McKinsey (2015), for example, highlights the importance of women for countries' economies. Regarding the United States of America, it is estimated that the country's Gross Domestic Product (GDP) would have been $25 \%$ lower had there not been an expressive entry of women into the labor market since the 1970 s (Barsh \& Yee, 2011). There is also evidence that gender diversity has a positive impact on the management of organizations.

I know from personal experience that gender diversity leads to better performance, a more inclusive culture and more balanced decisions (Peter Bodin, Global CEO, as referenced in Grant Thornton International, 2019, p. 6).

Despite these evidences, women face a number of difficulties in the labor market. Firstly, they are often segregated into less socially recognized occupations. For example, housekeepers are mostly women. Another example can be found in healthcare, where nurses are predominantly women, while most doctors are men, although this difference has narrowed over time (Bruschini, 2007).

In addition, evidence indicates that women are paid less than men, even in equivalent positions. This phenomenon is called gender pay gap and occurs when "[...] for the same levels of education, experience and controlled by other factors that would have an impact on the productivity of both sexes, a wage difference is observed between genders" (Madalozzo, Martins \& Lico, 2015, p. 1).

Finally, it is worldwide noted that women are underrepresented in the upper echelons of organizations, although there has been progress in this area as well. A global research conducted by Grant Thornton International (2019) - with 4,812 companies from 32 countries - points out that only $29 \%$ of leadership positions in organizations are occupied by women, a percentage that reaches $34 \%$ in Brazil.

Another study, involving 532 companies with headquarters or operations in Brazil, shows that $19 \%$ of leadership positions are held by women. As the importance of the position increases, this percentage decreases, as illustrated in Figure 2 (Talenses-Insper, 2019). 
Figure 2

Women's participation in leadership positions

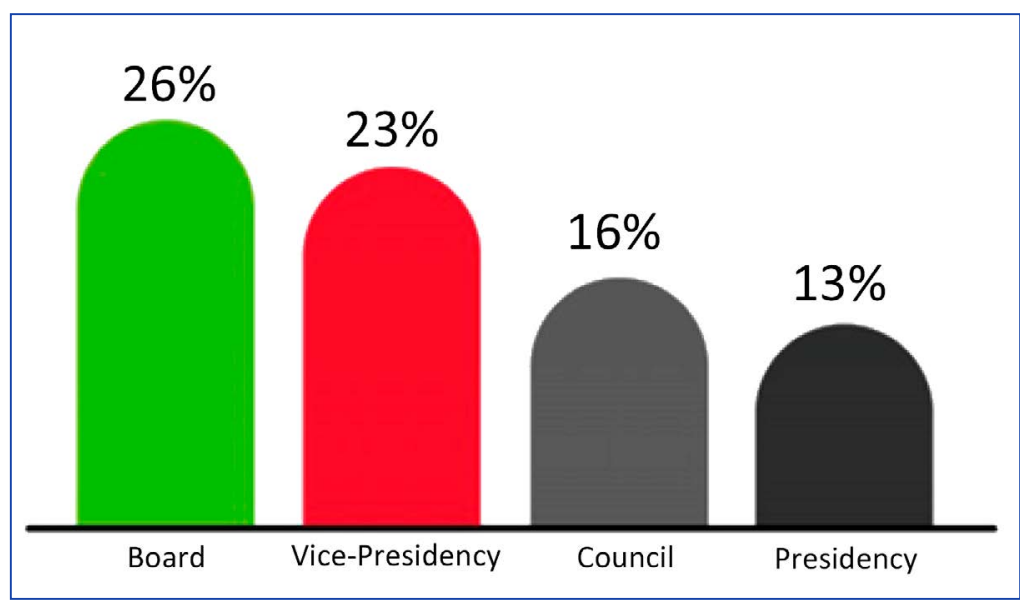

Source: Talenses-Insper (2019).

This difficulty for women to access positions of greater responsibility and prestige is attributed to the expression "glass ceiling", understood as an important, but sometimes imperceptible barrier that is thought to block women's access to the upper levels of the organizational hierarchy (Eagly \& Carli, 2007; Steil, 1997).

Which factors would explain the existence of the glass ceiling? Rutherford (2014) draws attention to the fact that the culture of organizations has been built based on the interests of men, leading women to feel like "outsiders". The author, for example, points out that an organization's culture is strongly influenced by its past and that most of them were founded by men and are predominantly led by men.

Eagly and Carli (2007) draw attention to four important aspects:

- Prejudice against women causes men to be privileged in selection processes, even with equivalent qualifications.

- There is resistance to female leadership based on the perception that women in leadership positions are more selfish, treacherous and demanding.

- Women might struggle to define their own style of leadership, since they feel divided between a more aggregating style (common to women) and more assertive attitudes, perceived as necessary for successful leaders.

- Family demands, which often lead women to interrupt their careers or that make it difficult to participate in activities necessary for their advancement (for example, networking).

Regarding this last item, other studies indicate that many women give up higher positions in the hierarchy of organizations because they understand that the benefits do not outweigh the losses, especially in relation to the care and attention to the family (Silva \& Rossetto, 2010; Slaughter, 2012).

In addition, evidence indicates that the manager's perception of conflict zones between personal and professional life results in women being overlooked in promotion processes (Hoobler, Wayne \& Lemmon, 2009). The study by Brands and Fernandez-Mateo (2017) also pointed out that the experience of rejections in selection processes is another factor that contributes to the under-representation of women in higher positions in organizations.

In summary, the literature shows us that the phenomenon of the glass ceiling is multifaceted and that its overcoming still seems far from being achieved, despite the important advances observed in recent years. 


\section{REFERENCES}

Barsh, J., \& Yee, L. (2011, April 01). Unlocking the full potential of women in the US economy. McKinsey \& Company. Retrieved from https://www.mckinsey.com/business-functions/organization/ our-insights/unlocking-the-full-potential-of-women\#

Blanchard, K. (2012). Liderança de alto nível: como criar e liderar organizações de alto desempenho. Porto Alegre, RS: Bookman.

Bohlander, G. W., \& Snell, S. A. (2015). Administração de Recursos Humanos. São Paulo, SP: Cengage Learning.

Brands, R. A., \& Fernandez-Mateo, I. (2017). Leaning out: How negative recruitment experiences shape women's decisions to compete for executive roles. Administrative Science Quarterly, 62(3), 405-442. Retrieved from https://doi.org/10.1177/0001839216682728

Breaugh, J. A. (2008). Employee recruitment: Current knowledge and important areas for future research. Human Resource Management Review, 18(3), 103-118. Retrieved from https://doi.org/10.1016/j. hrmr.2008.07.003

Brito, R. P., \& Oliveira, L. B. (2014). A relação entre gestão de recursos humanos e desempenho organizacional. Brazilian Business Review, 13(3), 94-115. Retrieved from https://doi.org/10.15728/bbr.2016.13.3.5

Bruschini, M. C. A. (2007). Trabalho e gênero no Brasil nos últimos dez anos. Cadernos de Pesquisa, 37, 537-572. Retrieved from https:// doi.org/10.1590/S0100-15742007000300003

Dessler, G. (2013). Human Resource Management (13a ed.). Upper Saddle River, NJ: Pearson Education.

Eagly, A. H., \& Carli, L. L. (2007). Women and the labyrinth of leadership. Harvard Business Review, 85(9), 63-72.

Goleman, D. (2000). Leadership that gets results. Harvard Business Review, 78(2), 4-17.

Grant Thornton International. (2019, March 08). Women in business: construindo um plano de ação. Retrieved from https:// www.grantthornton.com.br/insights/artigos-e-publicacoes/ women-in-business-2019/

Hoobler, J. M., Wayne, S. J., \& Lemmon, G. (2009). Bosses' perceptions of family-work conflict and women's promotability: Glass ceiling effects. Academy of Management Journal, 52(5), 939-957.

Madalozzo, R., Martins, S., Lico, M. R. (2015). Segregação ocupacional e hiato salarial entre os gêneros (Working Paper, n. 357). São Paulo, SP: Insper.
McKinsey. (2015). The power of parity: How advancing women's equality can add \$12 trillion to global growth. New York, NY: McKinsey Global Institute. Retrieved from https://www.mckinsey. com/featured-insights/employment-and-growth/how-advancingwomens-equality-can-add-12-trillion-to-global-growth\#

Nkomo, S. M., Bell, M. P., Roberts, L. M., Joshi, A., \& Thatcher, S. M. B. (2019). Diversity at a critical juncture: New theories for a complex phenomenon. Academy of Management Review, 44(3), 498-517. Retrieved from https://doi.org/10.5465/amr.2019.0103

Robbins, S. P., Judge, T. A., \& Sobral, F. (2011). Comportamento organizacional: uma perspectiva brasileira (14a ed.). São Paulo, SP: Pearson.

Rutherford, S. (2014). Gendered organizational cultures, structures and processes: the cultural exclusion of women in organizations. In R. J. Burke \& D. A. Major (Eds.), Gender in Organizations. Cheltenham, UK: Edward Elgar Publishing.

Ryan, A. M., \& Ployhart, R. E. (2014). A Century of Selection. Annual Review of Psychology, 65(1), 693-717. Retrieved from https://doi. org/10.1146/annurev-psych-010213-115134

Shore, L. M., Chung-Herrera, B. G., Dean, M. A., Ehrhart, K. H., Jung, D. I. ... Singh, G. (2009). Diversity in organizations: Where are we now and where are we going? Human Resource Management Review, 19(2), 117-133. Retrieved from https://doi.org/10.1016/j.hrmr.2008.10.004

Silva, A. B., \& Rossetto, C. R. (2010). Os conflitos entre a prática gerencial e as relações em família: uma Abordagem complexa e multidimensional. Revista de Administração Contemporânea, 14(1), 40-60. Retrieved from https://doi.org/10.1590/S1415-65552010000100004

Slaughter, A. M. (2012, July/August). Why women still can't have it all. The Atlantic. Retrieved from https://www.theatlantic.com/ magazine/archive/2012/07/why-women-still-cant-have-it-all/309020/

Steil, A. V. (1997). Organizações, gênero e posição hierárquica: compreendendo o fenômeno do teto de vidro. RAUSP Management Journal, 32(3), 62-69.

Talenses-Insper. (2019). Panorama Mulher 2019 (3a ed.). São Paulo, SP: Talenses Group and Insper. Retrieved from http://online.fliphtml5. com/gbcem/wbwh/\#p=1

Yukl, G. (2013). Leadership in organizations (8a ed.). London, UK: Pearson Education. 
Master's student in Administration at Faculdades Ibmec-RJ. E-mail: luizawanke@globo.com

Vivian Luiz Coco

ORCID: https://orcid.org/0000-0002-6220-3343

Master's student in Administration at Faculdades Ibmec-RJ. E-mail: vivian.coco@lickslegal.com

Lucia Barbosa de Oliveira

ORCID: https://orcid.org/0000-0001-7792-5552

Ph.D. in Administration by Instituto Coppead de Administração (Coppead-UFRJ); Professor at Escola Brasileira de Administração Pública e de Empresas (FGV EBAPE). E-mail: lucia.oliveira@fgv.br

Ana Christina Celano Teixeira

ORCID: https://orcid.org/0000-0002-4521-7399

Ph.D. in Administration by Escola Brasileira de Administração Pública e de Empresas (FGV EBAPE); Professor of Master in Administration at Faculdades Ibmec-RJ. E-mail: anacelano@gmail.com 